\title{
GEO-TOURISTIC STUDY OF THE ALBANIAN IONIAN COASTLINE
}

DOI: http://dx.doi.org/10.18509/GBP.2015.34

UDC: $338.483(496.54262 .22)$

\author{
Doc. PhD. Gentian Ruspi \\ Department of Geography, University “Eqrem Çabej”, Gjirokastra, Albania.
}

\begin{abstract}
According to the World Tourism Organisation (UNWTO) data, tourism in the world is a growing activity. Only for the year 2013 the world ranging number of tourists was raised to $5 \%$ thus, transforming it into a economic factor with a positive growth. This activity growth noticed in Albania during recent years, is characterised by a positive sustainable tendency growth in the nation economy. This factor has become an object of research for geographical studies.

This paper is focused on the geo-tourictic study in the Albanian Ionian (NW-SE) coastline of 154 kilometres length and with considerable width of $7-8$ kilometers within the territory. This area is one of the most attractive places for the tourists that visit Albania. As such it is of interest for the geographical studies to promote the natural and cultural herritage as well as the local market.

The first part of this paper deals with the geo-touristic position of the area. The second part evaluates the development strategies of tourism and its impact on this area as well as the primary natural, historical and cultural offers. In the last part the paper concludes with the study presenting the features of the touristic humanism as well as the framework for the future development.

Through the calculation of the touristic optimal limits of the volume we intend to give the relevant recommendations in order to prevent degradation. The methodology used for this study is based on: data collection, processing and analysis; the study of related literature; computer processing and prognosis.
\end{abstract}

Keywords: geo-tourism; touristic strategies; touristic resources; touristic humanism; touristic environment.

\section{INTRODUCTION}

Notion of touristic humanism as a continuously changing process, in quantity and quality point of view is the basement to understand urban-territory processes, especially those that have to do with the presence of a dominant economic activity such as tourism. Touristic humanism is used to describe urban growth from demographic and space point of views, or to be used to describe special features of an urban area or an area under development from the services offered, housing and basic infrastructure point of views. In Ionian coastline urbanization process creates a strong subordination rapport with tourism. This is showed better through the tendencies of urban growth (a demographic and space growth) and development pace of tourism sector.

\section{MATERIALS AND METHODS}

In order to get the desired results this research was based in: analyzes of statistical data (in local, regional, national and international level); studying of documents and mapping materials; especially during the last researches based on the necessity of scenarios for the tourism development in the future. Among the above mentioned data for the realization 
of this research are used even data taken in indirect way or additional data through surveys, questionnaires, polls, calculations and comparisons and verifications on site. The methodology used for this study is based on: data collection, processing and analysis; the study of related literature; computer processing and prognosis.

\section{GEO- TOURISTIC POSITION}

Ionian coastline is situated in Albanian territory according to geographical direction northwest-southeast from the Gjuhëza Cape (in Karaburun Peninsula), up to Ftelia Bay in Stillo Cape with a coastline length round $154 \mathrm{~km}$. Meanwhile according to the geographical direction southwest- northeast, this area analyzed in this reasearch, is situated from the coastline line up to watershed line with a width from $2-3 \mathrm{~km}$ up to 7-8 $\mathrm{km}$. The area taken in consideration under this reasearch is situated in Vlora Region in its Southwestern part.

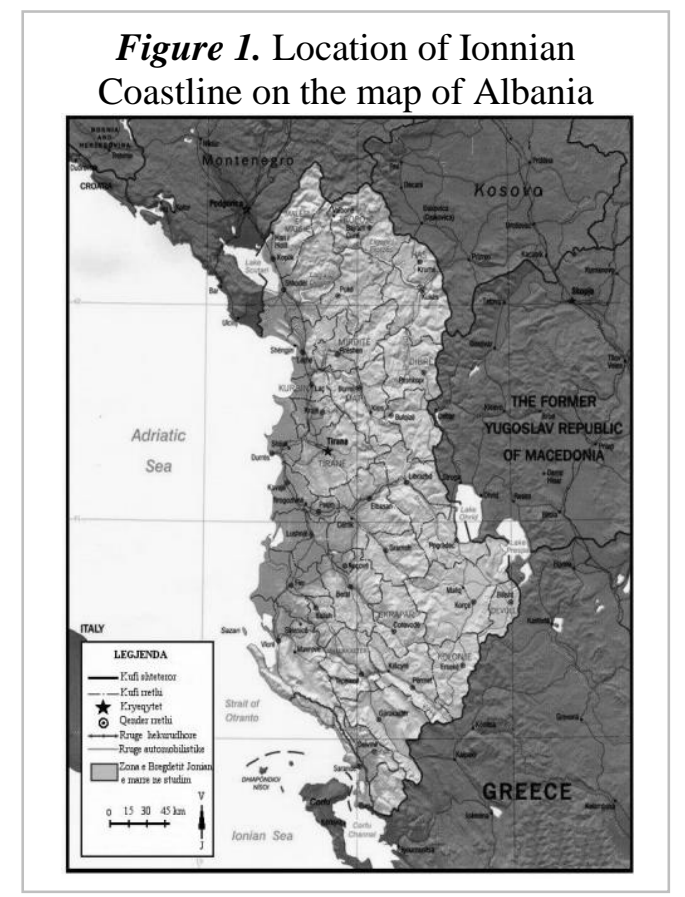

Touristic activation of this area have had an essential impact that derived from naturalgeographic primary offer, which is rich of many diverse attractive elements, such are: the presence of Ionian Sea, rocky coastline, diverse beaches (with ballasts, pebbles and coarse sand), favourable climatic conditions, clean environment (as the result of far distance from noisy urban centres), relief with diversity of forms, water assets etc.

In the space taken in consideration in this reasearch is showed up a tipical Mediterranian subtropical climate, where an important impact in the change of climatic features has the prezence of Ionian Sea. Based on the Albanian climatic regionalization [1] this area is part of Mediterranian field climate and the subarea Mediterranian south field climate.Solar radiation in the Coastline area is very high.According to the data of Borsh station the general radiation value are $1495 \mathrm{kwh} / \mathrm{m}^{2}$, Total of sunny hours is 2442 hours/year, while the number of sunny days is 332 . Annual average temperature is $17^{\circ} \mathrm{C}$, January average temperature is from $9.5^{\circ} \mathrm{C}$ to $10^{\circ} \mathrm{C}$, while August average temperature $30^{\circ} \mathrm{C}$ or more. This issue has a special value for the tourism tipolgy.

Lack of plants especially in the forests is as the result of human being intervention. Most of the territory is covered with Mediterranean MAQUIS.

Geo touristic position of Ionian Coastline is very favourable, since the region is part of Mediterranean area. Round 1/3 of all worlds touristic movements are concentrated in Mediterranean area, especially in the summer season [7]. Region position is such important, that put it in front of areas, regions and states which are part of a very competitive market in tourism field such are: Italy, Turkey, Greece and Croatia (see tab. nr. 1.). 
Table 1 Arrival of tourist in mediterranean countries (in Southern Europe) for the period 2010-2012. [10]

\begin{tabular}{|l|r|r|r|r|r|}
\hline \multirow{2}{*}{ Destinations } & \multicolumn{5}{|c|}{ International Tourist Arrivals } \\
\cline { 2 - 6 } & \multicolumn{3}{|c|}{$(\mathbf{1 0 0 0})$} & \multicolumn{2}{c|}{ Change (\%) } \\
\cline { 2 - 6 } & \multicolumn{1}{|c|}{$\mathbf{2 0 1 0}$} & \multicolumn{1}{c|}{$\mathbf{2 0 1 1}$} & \multicolumn{1}{c|}{$\mathbf{2 0 1 2}$} & $\mathbf{2 0 1 1 / 2 0 1 0}$ & $\mathbf{2 0 1 2 / 2 0 1 1}$ \\
\hline \multirow{2}{*}{$\begin{array}{l}\text { Southern/Mediterranean. } \\
\text { Europe }\end{array}$} & 173,317 & 186,930 & 190,441 & 7.9 & 1.9 \\
\hline Albania & 2,191 & 2,468 & 3,156 & 12.6 & 27.9 \\
\hline Andorra & 1,808 & 2,242 & 2,238 & 24.0 & -0.2 \\
\hline Bosnia \& Herzg. & 365 & 392 & 439 & 7.2 & 11.9 \\
\hline Croatia & 9,111 & 9,927 & 10,369 & 9.0 & 4.5 \\
\hline Cyprus & 2,173 & 2,392 & 2,465 & 10.1 & 3.0 \\
\hline Macedonia & 262 & 327 & 351 & 25.1 & 7.3 \\
\hline Greece & 15,007 & 16,427 & 15,518 & 9.5 & -5.5 \\
\hline Israel & 2,803 & 2,820 & 2,886 & 0.6 & 2.3 \\
\hline Italy & 43,626 & 46,119 & 46,360 & 5.7 & 0.5 \\
\hline Malta & 1,339 & 1,415 & 1,443 & 5.7 & 2.0 \\
\hline Montenegro & 1,088 & 1,201 & 1,264 & 10.4 & 5.3 \\
\hline Portugal & 6,832 & 7,412 & 7,685 & 8.5 & 3.7 \\
\hline San Marino & 120 & 156 & 139 & 30.3 & -10.9 \\
\hline Serbia & 683 & 764 & 810 & 11.9 & 6.0 \\
\hline Slovenia & 1,869 & 2,037 & 2,156 & 9.0 & 5.8 \\
\hline Spain & 52,677 & 56,177 & 57,464 & 6.6 & 2.3 \\
\hline Turkey & 31,364 & 34,654 & 35,698 & 10.5 & 3.0 \\
\hline
\end{tabular}

Figure 2. Chart of the arrival of tourist in Mediterranean countries (in Southern Europe) for the period 2010-2012. [10]

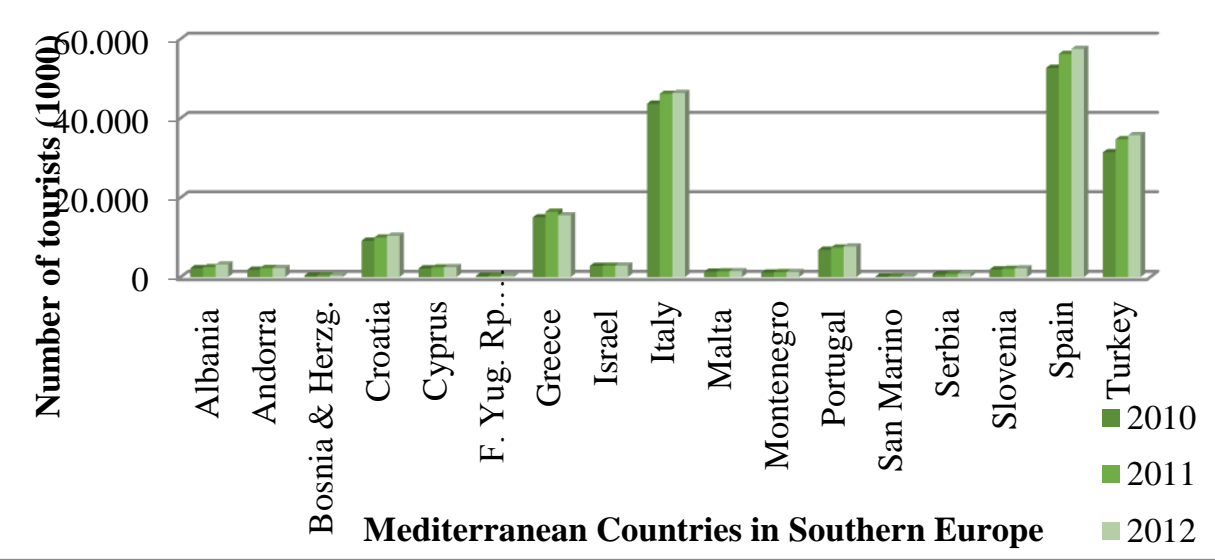

Figure 3. Chart of the change $\%$ in arrival of tourist in Mediterranean countries (in Southern Europe) for the period 2010-2012. [10] 


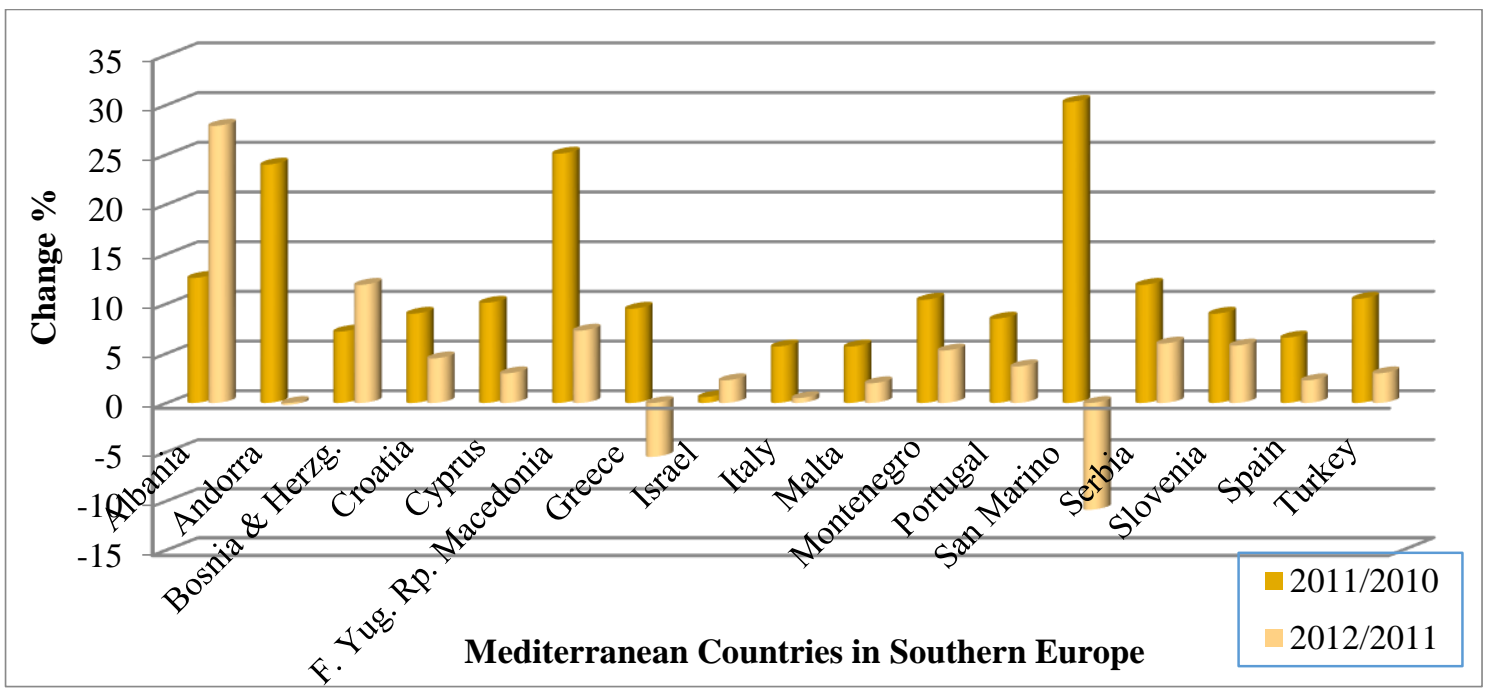

For the period of time 2010-2012 in most of Mediterranian touristic destinations as the result of the global economic crise, the increased percentage of tourist number for have been very low. Albania is part of those countries with highest increase of tourist number in Mediterranian area for this period of time (See table 1 and graphs above). In rapport with other countries, Albania holds the first place in \%, related to the increasing number of tourists from one year to another (see figure 3.), despite it has a small surface. This increase of tourists number in Albania is reflected even in Ionian Coastline having is consideration that this area is one of the most touristic attractive areas.

\section{OFFERS OF BEACHES FOR THE TOURISM DEVELOPMENT}

Assessed from the primary offer, this area part of the research, possess natural and cultural resources for the development of elite tourism. One of the most attractive natural resources of this area are the beaches. Despite the coastline considerable length of the area part of this research $(154 \mathrm{~km})$ beaches have a limited elongation with a lot of intermissions, concentrated mainly in bays, this as the result of the rocky rugged relief. Anyway these beaches are very attractive interweaved in harmony with waters of Ionian Sea.

Along the coastline taken in consideration under this research, in general the beaches have a physical carrying capacity (PCC) of 104390 tourists, based on formulae given by Cifuentes (1992) [3] and recommended by IUCN [2]. In the concrete terrain through the polls in overcrowded days, this number is calculated to be 52.000 tourists, which shows that are used only half of PCC. Regions beaches surfaces which are available to vacationers is calculated to be round $441660 \mathrm{~m}^{2}$ (44.166 ha). Coastline length of these beaches is calculated to be round $28,235 \mathrm{~km}$ (based on the measurements done during this research). Based on the coastline length of the area part of this research, beaches holds round $18,3 \%$ of all this length, which prove the character of rocky coastline.

In different literatures optimal number of tourists per each beach surface unit is different. For the area part of this research the calculations are done having in consideration the criteria that to each tourist belongs $4 \mathrm{~m}^{2}$ surface, this is result of the fact that beaches in most of the cases have small dimensions. Allowed maximum of visitors fitting to the environmental and socio-economic parameters, and the tourism damages is expressed through Real Carrying Capacity (RCC) [2]. For the Albanian Ioanian Coastline, RCC is 27030 (tourists/days). If we compare the number of tourists which visit the beaches of 
Albanian Ioanian Coastline in the peak touristic period with RCC is noticed that this beaches accommodate almost double of RCC.

A great importance in calculation process of beach surfaces for touristic use has also the construction of buildings. Based on the suggestions of Development Plan of Albanian Ionian Coastline accommodation structures at Albanian beaches are recommended to be constructed at least $100 \mathrm{~m}$ far from the coastline from the waterline affected from the tide process. [9]

From the field observations was found that some of the beaches have reached time ago the optimal number of the tourists accommodated there, and some of them have exceed this number a fact made evident from the high density of tourists who frequented these beaches. In the distribution of tourists to specific beaches within the region a great role play factors such are: natural conditions and their beauty, touristic infrastructure, transport conditions, advertisements, tourists' preferences, cost of expenses etc.

Among the attractive beaches with high accommodation capacities we can mention: Borsh Beach $\left(94000 \mathrm{~m}^{2}\right)$; Dhërmi Beach $\left(53000 \mathrm{~m}^{2}\right)$; Saranda Beaches $\left(36000 \mathrm{~m}^{2}\right)$; Palasa Beach $\left(34000 \mathrm{~m}^{2}\right)$; Livadh Beach $\left(27500 \mathrm{~m}^{2}\right)$; Himara Beach $\left(25000 \mathrm{~m}^{2}\right)$; Lukova Beach $\left(24400 \mathrm{~m}^{2}\right)$; Ksamil Beach $\left(13400 \mathrm{~m}^{2}\right)$ etc.

\section{IOANIAN COASTLINE ON THE FOCUS OF STRATEGIES FOR TOURISM DEVELOPMENT}

Ioanian coastline is characterised from the specific features in rapport wit other part of Albanian coastline. During the last decades is noticed: quick deveopment, uncontrolled constructions, environmental problems but also great economic possibilities. In order to control these developments in this part of Albanian coastline, as one of the elite areas of Albania, are done attempts from different institutions through masterplans and national or local strategies. One of the strategies with great interest for the Albanian coastline, especially for the area part of this research, was that of 2013 approved from Albanian Government "Tourism development strategies in Albania up to 2012" [5]. In concept this strategy was foreseen actions which intend to encourage tourism development in Albania. Refering to this strategy for the Ionian Coastline the foreseen measures were really useful and with a positiv vision for the future of this area. Product of this strategy was also the approval in July 2008 "Development Plan of Southern Coastline".

Based on the need to review the Tourism Development Strategy 2002-2012 and interrelation of it with Strategy and Action Plan for the Environmental and Natural Tourism Development, Albanian government in 2008 approved another decision with a great interest for the development of tourism, such as: "The law for approval of sector tourism development for the period 2007-2013" [4]. According to this strategy for the Ionian Coastline, the product development should have as its aim to offer to visitors a combination of experiences based on the combination of attractive products which have as basic elements natural and cultural environment.

In this strategy is defined specifically that area should be reserved for the development of high level tourism, hotels, resort villages with low altitude and a density of 100 tourists/ha, designed to create small possible changes in rapport with natural environment and local topography. In relation to the marine development and facilities, strategy recommended the use of coastline physical forms. Meanwhile in the existing villages, along the coastline, the strategy has foreseen their integration, not only in the constructed environment but also in the economic and social terms. 
About the development of tourism in Albania during the last two decades are designed different researches and strategies which have included the area part of this research, but the Master-plan, which is dedicated to the development of Ionian Coastline is " Development plan of southern coastline". [6]

This Master-plan consists in three parts:

- Research study of the development

- Development Plan

- Policy Action Plan.

Specialists, who have been selected from two partners, PAP/RAC ${ }^{12}$ (Croatia) and SOGREAH ${ }^{13}$ (France, as part of a consortium), analyzed all the sectors related to Albanian Southern Region. Satellite images of southern region taken in April 2005, were taken and processed, and was prepared a database GIS. This database provided an information source which was not evident before in Albania and never used for the planning of land usage.

Plan in its essential part consist in many positive aspects related to analyzes, assessments, conclusions and recommendations. Among the positive aspects this plan has also its weak points which are noticed through the difficulties for its use in field and which consist mainly in:

- Discordances between policies and strategies of this plan with the reality of social economic developments in general, and the tourism development in the concrete terrain of this area part of the research.

- Non all the local and central institutions have proper knowledge and assessment for this plan and as the result of it I some cases were showed unclear points even conflicts.

Some of the risks which are an obstacle for the use of strategies are related to:

-The instable political, social and economical development. Albania represents a country with a democracy under construction. Empowering of laws and institutions will need time engagement of responsible structures and sustainability of developments in whole country; in contrary we will face obstacles for the tourism developments in the region.

-Non foreseen tendencies which are result of land and territory usage. In the area part of this research agricultural land is under the usage level, in comparison with the situation before 1990; interior dwelling places which are subordinated from the agriculture, are facing depopulation and the use of land for agricultural purposes is decreased; increasing of population density along the coastline is encouraged from the expectations to gain incomes from the tourism and financed in most of the part from the savings of individuals have brought a mixed and irregular usage of free land area along the coastline.

-Land ownership. Land ownership along the coastline is still not solved from the government and it seems to be an essential problem for the development. Policies aim to follow the law implementation "For the return and compensation of former property owners" [8], aim to fulfil most of the former property owners requirements for the land compensation along the coastline. These policies have not been done through prior

12 PAP/RAC - Priority Actions Programme/Regional Activity Centre

13 SOGREAH - Societe Grenobloise d'Etudes et d'Application Hydrauliques 
analyzes, benefits and problems that will bring about the sustainable development in the whole region.

Use of strategies in respective field shows the fact that they should be flexible, since they need more improvements and adoption in function to the best ways for the regional developments. At the same time these adoptions should serve to the long term and sustainable development of the area.

\section{COASTLINE TOURISTIC HUMANISM AND DEVELOPMENT SCENARIOS}

Introduction with the touristic humanism level along the Ionian Coastline is related to the geo-touristic area analyzes. Tourism development models of Ioanian Coastline reflects the same role of natural,human resources and the impacts from the social, political and economical developments in our country. Among the common and unity elements that possess, the area under the study research is distinguished even for the special features of touristic development models in different part of the region.If we were going to classify touristic areas of this region according to the number, economic social and cultural level, of tourists who visit them we were going to distinguish these areas:

- Tourists massive concentration areas. This area has showed the tendencies to be developed in Saranda town (part of the town from the harbour up to the end of promenade). Among the features which characterize this area are: great number of visitors (rapport tourists/residents over $2 / 1$ in the peak period), high level of urbanization (non urbanized are from the ecological and touristic point of view) with tendencies to occupy the free public areas, several construction without criteria (high buildings,close to each other and in discordance with urban criterias), overcrowded beaches with vacationers, infrastructure problems (drinkable water, electricity power, main roads etc), high pollution levels (of water, air, beaches and acoustics) and modest touristic accomodation structures. Tourists who frequent this area with massiv concentration do not have many requirments for the accomodation conditions spent less (have less incomes).

- Areas with middle pace level of flux and touristic developments. Represent touristic spaces more distinguished in he region which attract the greatest number of tourists. In this area, flux of visitors is in accordance with optimal accomodation capacities of natural and cultural environment. Among most distinguished areas can be mentioned: Dhërmi, Himara, Borsh, Lukova, coastline area from Hotel Butrint up to Ksamil etc. Characteristic for these area are: clean beaches, sufficent spaces for the tourists accomodation, few constructions based on the traditions, low pollution levels and qualitative accomodation structures that offer services with prices over the average level of Ioanian Coastline. Most of the tourists who frequent these areas, regarding to the economic and socila level, belong to low, middle and class.

- Area of high level tourism. It includes some touristic spaces into which are included some touristic areas and where tourists shw requirments for a qualitative tourism. High level tourism is in its first steps. Turists of this category have high incomes and in general includes middle strata and high strata of society with a hih level of intelect. These areas where the tendency to develop such type of tourism is found in Dhërmi, Borsh and Lukovë.

- Area of elite tourism. In Ionian Coastline are foud many areas which possess the necessary resources in order to function as development areas of elite tourism, so these areas are introduces more or less as pontential areas. Actually as such area which attract many tourists of this category is National Park of Butrint (a site under UNESCO 
protection) and if in the future will have necessary investments in the region as such areas it can be functioned beaches of northern part of Ksamil, Manastir, Pasqyra, Kakomea Beaches of specific parts of Lukova and Dhermi Beaches which are a good base to urge their development toward elite areas.

Bazed on the development model as a feature of Ionian Costline is the fact that touristicnatural panorama is integrated and is replaced with urban -cultural panorama for tourism purposes ( this is noticed especially for the coastline area between Saranda and Ksamil) and are noticed first problems for the tourism development such are environmental, social services and accomodation capacities problems. Other touristic areas of Ionian Albanian Coastline in general have a panorama with sustaianble touristic- natural features. In definding the way how to realise touristic humanism of this area, an important role will have all actors who act in tourism field. Collaboration between all these actors to find out proper ways for a sustainable and long term tourism development in the region.

\section{REFERENCES}

[1] Albanian Academy of Science, "Klima e Shqipërisë (Albanian Climate)", Tiranë, pp: 8, 1975.

[2] Ceballos-Lascurain, H. Tourism, Ecotourism and Protected Areas. IUCN, Gland, Switzerland and Cambridge, UK, pp: 301, 1996.

[3] Cifuentes, M. Determinación de capacidad de cargaturística en áreasprotegidas. Ed. Turrialba, Costa Rica, pp: 34, 1992.

[4] Decision of Council of Ministers, Nr.844, "For apporval of sector tourism strategy for the period", Official Notebook Nr.107, Albania, pp:4732, 11.VI.2008.

[5] Decision of Council of Ministers, Nr.517, "For approval of development tourism strategy up to 2012”, Official Notebook Nr:67, Albania, pp: 2965, 3.VII.2003.

[6] Decision of KRRTRSH, Nr. 1, "For approval of designing task and the development plan of Southern Coastline", Albania, 17.VII.2008.

[7] Dh. Doka, B. Draçi, Gjeografia e Turizmit,(Tourism Geography) Tiranë: SHBLU, pp: 170, 2002.

[8] Law, Nr. 7698, "Return and Compensation of propertiies to their owners", Albania, 15.IV.1993.

[9] TBU-HBA-P\&P Joint Venture (Financed from World Bank), Ministry of Public Affair and Transports, Plan for the Development of Albanian Southern Coastline , Albania, pp: 34, November 2007 (Approved from KRRTRSH, on 17.07.2008).

[10] World Tourism Organization (May 2014), Tourism highlights, 2014 Edition, Available at: http://www.e-unwto.org (or available at: http://www.eunwto.org/content/r13521/fulltext.pdf), pp: 8-11. (Accessed: January 09, 2015). 